\title{
Home Pharmacy Care : Solusi Keberhasilan Terapi di Rumah
}

\author{
Ahmad Ahmad \\ Program Studi Profesi Apoteker, Fakultas Farmasi, Universitas Padjadjaran, Sumedang 45363 \\ email: ahmad14022@mail.unpad.ac.id
}

\begin{abstract}
Abstrak :
Pharmaceutical care menggeser paradigma praktik kefarmasian dari drug oriented menjadi patient oriented. Perubahan paradigma tersebut mempengaruhi bentuk pelayanan kefarmasian di komunitas, rumah sakit, puskesmas, maupun fasilitas pelayanan kesehatan yang lain. Konsekuensi dari perubahan paradigma tersebut maka apoteker dituntut untuk meningkatkan pengetahuan dan keterampilan agar mampu berkomunikasi dengan tenaga kesehatan lain secara aktif, berinteraksi langsung dengan pasien di samping menerapkan keilmuannya di bidang farmasi. Apoteker di sarana pelayanan kesehatan mempunyai tanggung jawab dalam memberikan informasi yang tepat tentang terapi obat kepada pasien. Home Care oleh apoteker adalah pendampingan pasien oleh apoteker dalam pelayanan kefarmasian di rumah terutama untuk pasien yang tidak atau belum dapat menggunakan obat dan atau alat kesehatan secara mandiri, yaitu pasien yang memiliki kemungkinan mendapatkan risiko masalah terkait obat misalnya komorbiditas, lanjut usia, lingkungan sosial, karateristik obat, kompleksitas pengobatan, kompleksitas penggunaan obat, kebingungan atau kurangnya pengetahuan dan keterampilan tentang bagaimana menggunakan obat dan atau alat kesehatan.
\end{abstract}

Keyword : apoteker, home care, terapi, obat

\section{Outline}

Pendahuluan

Manfaat Home Pharmacy Care

Pasien seperti apa yang memerlukan Home Pharmacy Care?

Tahapan Home Pharmacy Care

Kapan home pharmacy care sebaiknya dapat dihentikan?

Kesimpulan

\section{Pendahuluan}

Konsekuensi dari perubahan paradigma tersebut maka apoteker dituntut untuk meningkatkan pengetahuan dan keterampilan agar mampu berkomunikasi dengan tenaga kesehatan lain secara aktif, berinteraksi langsung dengan pasien di samping menerapkan keilmuannya di bidang farmasi. Apoteker di sarana pelayanan kesehatan mempunyai tanggung jawab dalam memberikan informasi yang tepat tentang terapi obat kepada pasien. 
Apoteker berkewajiban menjamin bahwa pasien mengerti dan memahami serta patuh dalam penggunaan obat sehingga diharapkan dapat meningkatkan keberhasilan terapi khususnya kelompok pasien lanjut usia dan pasien dengan penyakit kronis. Salah satu bentuk pharmaceutical care adalah home pharmacy care yaitu kepada pasien yang dilakukan di rumah khususnya untuk kelompok pasien lanjut usia, pasien yang menggunakan obat dalam jangka waktu lama seperti penggunaan obat-obat kardiovaskuler, diabetes, TB, asma dan obat-obat untuk penyakit kronis lainnya.

Home Care oleh apoteker adalah pendampingan pasien oleh apoteker dalam pelayanan kefarmasian di rumah terutama untuk pasien yang tidak atau belum dapat menggunakan obat dan atau alat kesehatan secara mandiri, yaitu pasien yang memiliki kemungkinan mendapatkan risiko masalah terkait obat misalnya komorbiditas, lanjut usia, lingkungan sosial, karateristik obat, kompleksitas pengobatan, kompleksitas penggunaan obat, kebingungan atau kurangnya pengetahuan dan keterampilan tentang bagaimana menggunakan obat dan atau alat kesehatan.

\section{Manfaat Home Pharmacy Care}

\section{Bagi Pasien:}

- Terjaminnya keamanan, efektifitas dan keterjangkauan biaya pengobatan

- Meningkatkan pemahaman dalam pengelolaan dan penggunaan obat dan/atau alat kesehatan

- Terhindarnya reaksi obat yang tidak diinginkan

- Terselesaikannya masalah penggunaan obat dan/atau alat kesehatan

Bagi Apoteker :

- Pengembangan kompetensi apoteker dalam pelayanan kefarmasian di rumah

- Pengakuan profesi farmasi oleh masyarakat kesehatan, masyarakat umum dan pemerintah

- Terwujudnya kerjasama antar profesi kesehatan.

\section{Pasien seperti apa yang memerlukan Home Pharmacy Care?}

Pasien yang perlu mendapat pelayanan kefarmasian di rumah antara lain:

- Pasien yang menderita penyakit kronis dan memerlukan perhatian khusus tentang penggunaan obat, interaksi obat dan efek samping obat

- Pasien dengan terapi jangka panjang misal pasien TB, HIVIAIDS, DM dll

- Pasien dengan risiko adalah pasien dengan usia 65 tahun atau lebih dengan salah satu kriteria atau lebih regimen obat sebagai berikut:

- Pasien minum obat 6 macam atau lebih setiap hari.

- Pasien minum obat 12 dosis atau lebih setiap hari.

- Pasien minum salah satu dari 20 macam obat dalam tabel 1 yang telah diidentifikasi tidak sesuai untuk pasien geriatric

- Pasien dengan 6 macam diagnosa atau lebih 
Tabel $1: 20$ (dua puluh) macam obat yang secara umum dipertimbangkan tidak sesuai untuk pasien lanjut usia (Twenty Drugs Considered Generally Inappropriate For Use in the Elderly)

\begin{tabular}{|l|l|}
\hline Diazepam & Indomethacin \\
Flurazepam & Cyclandelate \\
Pentobarbital & Methocarbamol \\
Amitriptyline & Trimethobenzamide \\
Isoxsuprine & Phenylbutazone \\
Cyclobenzaprine & Chlorpropamide \\
Orphenadrine & Propoxyphene \\
Chlordiazepoxide & Pentazocine \\
Meprobamate & Dipyridamole \\
Secobarbital & Carisoprodol \\
\hline
\end{tabular}

\section{Tahapan Home Pharmacy Care}

- Melakukan penilaian awal terhadap pasien untuk mengindentifikasi adanya masalah kefarmasian yang perlu ditindaklanjuti dengan pelayanan

- Menjelaskan permasalahan kefarmasian kepada pasien dan manfaat pelayanan kefarmasian di rumah bagi pasien

- Menawarkan pelayanan kefarmasian di rumah kepada pasien

- Menyiapkan lembar persetujuan dan meminta pasien untuk memberikan tanda tangan, apabila pasien menyetujui pelayanan tersebut.

- Mengkomunikasikan layanan tersebut pada tenaga kesehatan lain yang terkait, apabila diperlukan. Pelayanan kefarmasian di rumah juga dapat berasal dari rujukan dokter kepada apoteker apotek yang dipilih oleh pasien.

- Membuat rencana pelayanan kefarmasian di rumah dan menyampaikan kepada pasien dengan mendiskusikan waktu dan jadwal yang cocok dengan pasien dan keluarganya. Rencana ini diberikan dan didiskusikan dengan dokter yang mengobati (bila rujukan)

- Melakukan pelayanan sesuai dengan jadwal dan rencana yang telah Mengkoordinasikan pelayanan kefarmasian kepada dokter (bila rujukan)

- Mendokumentasikan semua tindakan profesi tersebut pada Catatan Penggunaan Obat Pasien.

\section{Kapan home pharmacy care sebaiknya dapat dihentikan?}

Home care dapat dihentikan apabila pasien memenuhi kondisi berikut :

- Hasil pelayanan tercapai sesuai tujuan

- Kondisi pasien stabil

- Keluarga sudah mampu melakukan pelayanan di rumah 
- Pasien dirawat kembali di rumah sakit

- Pasien menolak pelayanan lebih lanjut

- Pasien pindah tempat ke lokasi lain

- Pasien meninggal dunia

\section{Kesimpulan}

Home Care oleh apoteker diperlukan sebagai tanggung jawab dan upaya pendampingan dalam memberikan informasi yang tepat tentang terapi obat kepada pasien. Hal ini dialkukan terutama untuk pasien yang tidak atau belum dapat menggunakan obat dan atau alat kesehatan secara mandiri, yaitu pasien yang memiliki kemungkinan mendapatkan risiko masalah terkait obat misalnya komorbiditas, lanjut usia, lingkungan sosial, karateristik obat, kompleksitas pengobatan, kompleksitas penggunaan obat, kebingungan atau kurangnya pengetahuan dan keterampilan tentang bagaimana menggunakan obat dan atau alat kesehatan.

\section{Daftar Pustaka}

American Society of Health-System Pharmacist. 2000. ASDP Guidelines on the Pharmacist's Role in Home Care,. Diambil dari http://www.ashp.org/

American Society of Health-System Pharmacists. 2000. Home Care Pharmacy: Extending Clinical Pharmacy Services Beyond Infusion TherapyTriler D.M., Hamilton R.A. et al. Am J Health-Syst Pharm 57(14):1326-1331

Kemenkes RI. 2008. Pedoman Pelayanan Kefarmasian Di Rumah (Home Pharmacy Care). Jakarta: Kemenkes RI

Sreelalitha NEV, Narayana G, Padmanabha Y, Reddy RM. Review of Pharmaceutical Care Services Provided by The Pharmacist. IRJP 2012;3(4):78-79 